\title{
TOURISM AND DEVELOPMENT: LAND ACQUISITION, ACHIEVEMENT OF INVESTMENT AND CULTURAL CHANGE (CASE STUDY TOURISM INDUSTRY DEVELOPMENT IN BATU CITY, INDONESIA)
}

\author{
Abdul KODIR* \\ Universitas Negeri Malang, Faculty of Social Science, Sociology Department, \\ Bd, I1 Jalan Semarang No 5 Malang, Indonesia, e-mail: abdul.kodir.fis@um.ac.id
}

\begin{abstract}
Citation: Kodir, A., (2018). TOURISM AND DEVELOPMENT: LAND ACQUISITION, ACHIEVEMENT OF INVESTMENT AND CULTURAL CHANGE (CASE STUDY TOURISM INDUSTRY DEVELOPMENT IN BATU CITY, INDONESIA). GeoJournal of Tourism and Geosites, 21(1), 253-265. https://doi.org/10.30892/gtg.21120-285
\end{abstract}

\begin{abstract}
The objective of this study is to explain the impact of tourism development in Batu city, Indonesia. This study used qualitative research method. In collecting the data, the researcher conducted observation and in-depth interviews with some stakeholders in Batu City. This research found that the achievement of investment in Batu City exceeded the target from the targeted Medium Term Plan (RPJMD). Moreover, the regional economic growth reached 8.3\%. However, the development of tourism has had an effect on extensive land acquisition. In addition, the spatial planning taking place in Batu city depends on the investors. Consequently, the changes of spatial planning that accommodate the interests of capital influence the changes in the cultural value and mindset of Batu's society.
\end{abstract}

Key words: tourism, development, investment, land acquisition, cultural change

\section{INTRODUCTION}

The tourism sector is a strategic sector because it contributes to economic growth and create jobs in times of financial crisis in Europe and the uncertainty of the world economy, encourages and creates jobs, investment developments, increases public revenues and state financial revenues (Thompson, 2011; Kim et al., 2016; Du et al., 2016). Furthermore, the contribution of the tourism sector to both the world GDP and the provision of employment is increasingly high (Eugenio-Martin et al., 2008). In addition, the tourism sectors have also contributed to reduce the amount of poverty as it did in Costa Rica and Nicaragua (Vanegas et al., 2015). Further, on a more micro scale, tourism has contributed to engage the indigenous peoples in the search for development options (Capucci, 2016). As a sector of development that can spur the economic growth of a region (Cárdenas-García et al., 2015), tourism is considered as a strategic asset to encourage the development in certain areas that have the potential tourist attraction (Cárdenas-García et al., 2015). By the development of tourism industry in a region, urbanization that flows to

\footnotetext{
* Corresponding author
} 
big cities can be more suppressed. This case is because tourism has three aspects of influence namely the economic, social and cultural aspects. The tourism sector should be supported by all sectors such as local governments as managers, people who are in the location of tourism objects and the participation of private sectors as developers. The tourism sector also contributes greatly to the social and economic field in the community.

Batu City has the opportunity to be more developed as a more attractive tourism area; it is based on the very supportive natural conditions and geographical location. The tourism attractions in Batu city are made different from one to another, so there is no significant competition. Tourism resources owned by Batu City are quite diverse and can be easily found because of its relatively close location. This was further strengthened after Batu city government intensively launched Batu as a tourism city. In recent time, there is an increasing number of tourists who visit the city of Batu. Here of the number of foreign tourists who visit Batu City that were collected from 2011 to 2016 (Figure 1).

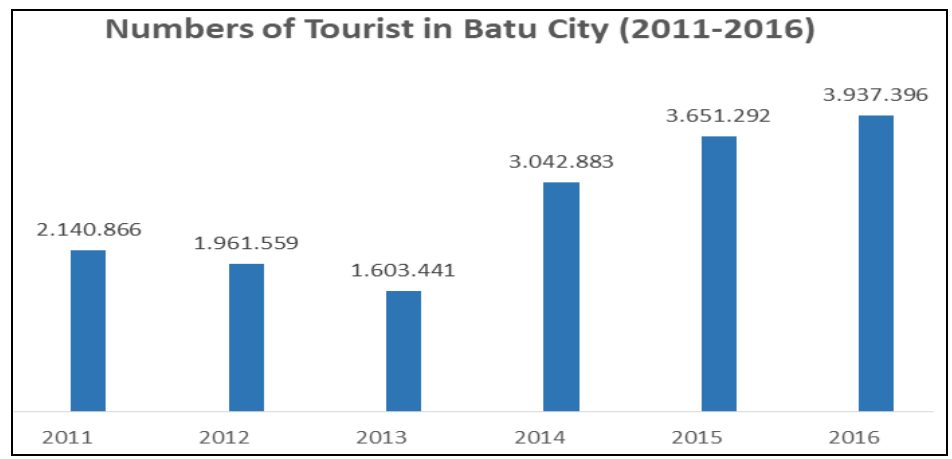

Figure 1. Number of Tourists Source: (Statistical Central Agency of Batu City, 2016)

It is also supported by the availability of adequate infrastructure, ranging from basic facilities (hotels, restaurants, and travel agencies), complementary facilities (recreational facilities and sports facilities), and supporting facilities (massage parlors). In addition, the existence of such infrastructure is well distributed (Muzha, 2013).

Tourism attractions in Batu City include Air Panas (Hot Water) Cangar, Selecta, Jawa Timur Park, Agro Kusuma and Songgoriti Park. The tourism attraction in Batu City are always full tourists because the location of Batu is on the highlands with beautiful scenery and a cool atmosphere so that the tourists feel comfortable in Batu City. In addition, within a period of about 10 years, Batu City is a city of tourism that is visited by many tourists both from within and outside the country. The development to attract tourists and also investors in the industry and tourism sector is intensively conducted (Yonanda, 2013). In addition, the increasing number of tourist sites also give an impact on the increasing number of tourism supporting facilities such as hotels and restaurants (Figure 2). However, there is a fundamental issue that obseved by the researchers or the other social scientists related to the expansion of tourism in \Batu City. Almost all research, which makes Batu City as a research site, is limited to the positivist paradigm where the research concluded that Batu city tourism has had a very positive effect especially on the improvement of Batu City original incomes and community involvement in the tourism industry. This research is to fill the vacancy of tourism development study of Batu city which tends to be pro status quo. Various researches conducted in Batu City only discussed the competitiveness of Apple commodities (Agustina, 2008), Tourism and Community Empowerment (Sukmana, 2012a; Muzha, 
Tourism and Development: Land Acquisition, Achievement of Investment and Cultural Change (Case Study Tourism Industry Development in Batu City, Indonesia)

2013), the effectiveness of licensing in increased investment (Yonanda, 2013), city tourism development model (Sukmana, 2012b; Maulida et al., 2012; Rahayu et al., 2013), tourism and city branding (Intyaswono et al., 2016). Almost no research that discusses the problems arising from the impact of tourism development in Batu City. Further, the studies on the impact of tourism and development on land acquisition and cultural change in Batu City are very rarely conducted among the researchers.

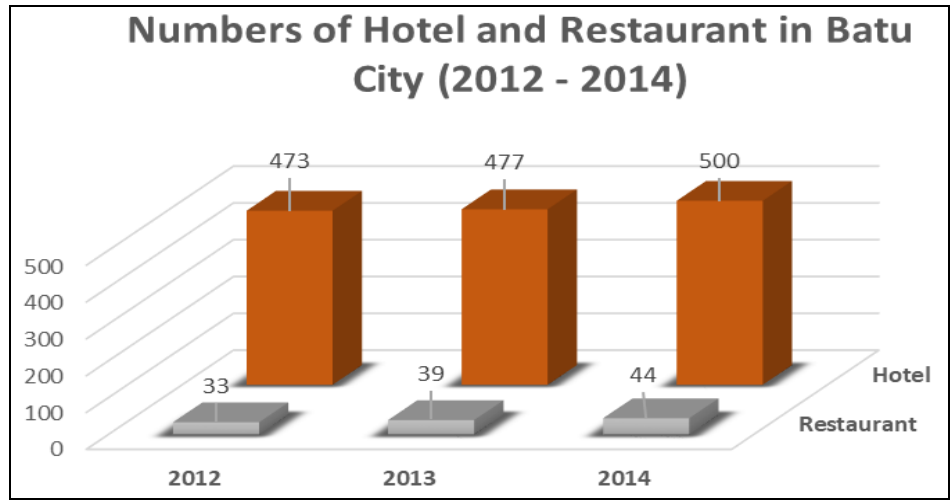

Figure 2. The Numbers of Hotel and Restaurant in Batu City (Source: Statictical Central Agency of Batu City, 2015)

\section{METHODOLOGY}

This research used qualitative research method. The qualitative research method is a multiple method in focus, which involves the interpretative and reasonable approach to each subject matter studied. This case means that qualitative research works in a natural setting and seeks to understand and interpret the phenomena seen from the meanings that people give to the phenomenon (Salim, 2006). The process of data collection was done by observation and in-depth interview. The techniques used to in determine the informants was purposive sampling. Some informants who have been interviewed in depth were such as legislative members from National Mandate Party (PAN - Partai Amanat Nasional), Environmental Agency (BLH - Badan Lingkungan Hidup), Investment Agency (BPM - Badan Penanaman Modal), Tourism and Cultural Agency (Dinas Pariwisata dan Kebudayan), National Land Agency (BPN - Badan Pertanahan Nasional), Humanist (Budayawan), Community Forum Care Springs (FMPMA - Forum Masyarakat Peduli Mata Air), Nawakalam Organization, Development Planning Agency (BAPPEDA - Badan Perencanaan dan Pembangunan), and Villages Supervisory Agency (BPD - Badan Pengawas Desa).

\section{RESULT AND DISCUSSION}

Land and development are the inspirable. Simply put that here is no landless development. In today's Indonesia, there is no such influential understanding as development. The implementation of this understanding gives a very significant change to the whole aspects of the land. The development always requires a site for the realization of projects, whether there are run by government agencies and companies, or privately owned by the companies (Rachman, 1997). In short, development forces for the procurement of an almost unlimited land. Not only in Indonesia, the increasing need for land for development also take place in India which started since neo liberal reform in 1991. It caused at least 10 million people lost their land (Karmakar, 2017). Although in 
some cases the land acquisition process also includes considerable compensation costs for land owners. However, market-based compensation is not sufficient to satisfy all heterogeneous landowners with different preferences (Dinda, 2016). Parwez and Sen (2016) added that the process of land acquisition for development always provides benefits to large companies and disadvantage to small peasants, agricultural laborers and indigenous people. The need for land to support development or which is subsequently presented in the term of land procurement for the public interest is inevitable (Pujiriyani et al., 2014). In this context, of course, the common welfare remains the estuary that is expected to be the breath of any land procurement activities undertaken. The need for land for development on the one hand and the need for land as the support and livelihood of the community on the other does require a wise management and attitude considering the presence of land and population pressure which from year to year also increasingly shows how the land becomes an increasingly expensive asset. Land acquisition is theoretically comprised of voluntary land acquisition and compulsory land acquisition. Broadly speaking, in Indonesia there are two types of land procurement namely land clearing for government purposes and land procurement for private purposes. Land procurement by the government is divided into land procurement for public interest and not public interest (Pujiriyani et al., 2014). Meanwhile, the procurement of land for private interests can also be classified into commercial and non-commercial interests, which are support the public interest or are included in the development of public facilities and social facilities.

However, in the process of land acquisition there is always a conflict which then hampers the development process (Wirabrata \& Surya, 2011). On the one hand, development requires land as the main means, while on the other hand, most people need the land as a settlement or agricultural productive land. If the land is taken for granted and used for government purposes, it means that the government sacrifice the human rights of the community that contains the rule of law.

To prevent such problems, the enactment of Law No. 12 of 2012 on Land Procurement and Government Regulation No. 71 of 2012 is an effort to protect the law in the procurement of land for the public interest of the community. This cae is to as far as possible avert or reduce the disputes in the form of preventive legal protection, and advice that should take precedence over repressive law protection facilities (Wangke, 2016). However in some articles, the Government Regulation collides with the Act thereon. As one example in Article 1, Point, 2 of Presidential Regulation No. 71 of 2012 determines that "Land procurement is the provision of land by providing fair and equitable compensation to the entitled Party" (Kristian et al., 2014). Judging from the meaning of the provision, it can be said that there is an element of coercion from the government to get the land of property right. Whereas, the Constitutional Law of 1945 prohibits the acts of arbitrariness, as set forth in the provisions of article 28 letter h paragraph (4) which stipulates that "every person has the right to own the right of private property and the right of property shall not be taken arbitrarily by people". Moreover, such legal status of ownership poses ambiguity in public opinion, and negatively affects local livelihood status and also leads to land use conflicts (Assembe-Mvondo et al., 2014).

Through the local governance policy, the central government empowers the local governments to undertake the development planning and control; planning, utilization, and control of spatial planning; organizing and public order; provision of public facilities and infrastructure. The authority given in its implementation is always misused by the local government (Langgeroni, 2015). The development involving individual land rights is taken over and controlled by the local government without the permission and even the legal knowledge of the landowner. Individual land ownership rights are taken over 
Tourism and Development: Land Acquisition, Achievement of Investment and Cultural Change (Case Study Tourism Industry Development in Batu City, Indonesia)

and controlled by the local government not for the public interest, but the local governments are concerned only with the interests of business actors in developing their economies. The local governments provide pressure and threats to the small communities who do not understand the law regarding the process of land procurement for the public interest to hand over their land. The land has an important meaning in human life because it has a dual function, namely as social assets and capital assets. As a social asset, land bind social unity among Indonesian society to live. Meanwhile, as a capital asset, land is a capital in development. In one side, land should be used and utilized for the greatest welfare of the people maximally, physically, fairly and evenly ditributed, while on another side the land must also be preserved (Senduk, 2015). The arrangement of land tenure and utilization for large-scale development supporting national or regional development efforts is implemented with due regard to political, social, defense and security aspects as well as environmental conservation. Meanwhile, the arrangement of land through land redistribution supports and accelerates regional development, poverty alleviation, and prevents land ownership gaps.

The public interest is the interest of all levels of society. The public interest is an activity that concerns the interests of the nation and the state, the wider community, the many people/ together, and/or the interests of development. Sometimes, this concept often creates ambiguity (Chettiparamb, 2016). Moreover, the definition of public interest as a rival private property (Ginosar, 2014; Lennon, 2017). The meaning of public interest in the procurement of land, among others, is the meaning that adopts local cultures, meaning that it involves the process of decision-making, has a focus on matters relating to the welfare of society, and treats society as a reason for formulating policy (Hasanah, 2012). Basically, the construction of land procurement for development for the public interest will depend on four things (Hamidah, 2014):

1) The legal status of the available land (in respect of the land to which the state lands or land belonging to the community with certain rights);

2) Legal status requiring land (government / certain government agencies or private sectors);

3) Allotment of controlled land (to build for the public interest or private enterprise);

4) The landowners' presence or absence of ownership.

The process of land acquisition for development for the public interest, based on the rule of law established by the authorized state institution is based on the legal aspect of the law respect and protect the interests of the community as much as possible (Hamidah, 2014). Legal politics in land procurement for the development of public interest has an important value to prevent land conflicts. The long series of conflicts over land are possible because land is one of the most valuable commodities if it is traded.

The land including assets other than having high economic value is also an item for the continuity of investment business activities. The land does not directly give welfare to the people the thing which gives prosperity is the activity of human beings on it manifested in its utilization. The availability of land for investors (investment) becomes a fundamental pre-requisite. Since the mid-1980s, the land supply arrangements have been made. One of them is the Minister of Home Affairs Regulation number 12 of 1984 concerning Procedures for Land Acquisition and Land Rights Grant, Building Permit and Business License for Distributing Companies. Regulation of the minister of the interior makes the foreign investment as well as domestic investment easy to obtain the land. This case observes the global capital behavior phenomenon, which since the early 1980 s it has been an industrial relocation from developed countries to developing countries. Relocation is meant in addition to seeking abundant natural resources, cheap labor, a conducive political climate 
as well as ease in the provision of land. Recently, the linkage between investment and landkeeping for both public and private interests are inseparable. It is because Indonesia is doing the main development of city which is not only financed through state funds budgeting $(A P B N)$ but also from the investment of both foreign and domestic investors. One of the developments at this time is often done by investment tourism. This case indicates that tourism is one sector of the economy that contributes greatly to the economic development of a country. Based on the data from the Central Bureau of Statistics in 2012, the share of national tourism was 13.9 percent of total Gross Domestic Product and of course with the large contribution of the sector, it is useful for the national economic growth, through the acceptance of foreign exchange received from the amount of consumption of the tourists to the product and national services (Singagerda et al., 2013).

\section{Land Acquisition and Achievement of Investment}

The widespread of land acquisition in Batu City coincides with global land acquisitions relating to global market demands, domestic growth targets and poverty alleviation that are ultimately resolved by the acceleration and optimilization strategy of land for development. Land acquisition is considered a solution. Some literature that found some scenarios behind the lan acquisition are others Zoomers (2012), White (2012) and Bollin (2011). Some researchers mentioned that the main factors driving the global land acquisition are the threat of food crisis, energy crisis, and the provision of an exclusive economic zone. However, Zoomers (2012) added that one of the causes is also among the tourism business. What is in Batu city theoretically reinforces what Zoomers (2012) mentioned that tourism development has a role in the effort of mass land acquisition. The demand for land for tourism development or anything that supports tourism increases every year. This case is based on the number of tourists in Batu City which increases in each year (Figure 1). In addition to the tourism business, the land acquisition is also caused by the private purchase of land where Pujiriyani et al., (2014) refers to it as land laundering. Land laundering or the purchase of land privately became one of the triggers of the massive land acquisitions, because when land becomes a private ownership, landowners can directly divert their lands when an agreement between the two parties has occurred (Pujiriyani et al., 2014). The are at least to reasons behind the occurrence of private puchase of land in Batu city. First, they want to develop a good business in the form of trade or build a villa that they can rent. Second, they buy land or houses in Batu with the intention of a shelter house while in holiday to cut the cost of accommodation.

Globally, the main actor who plays a significant role in land acquisition is the government (Quizon, 2012). In this case, it can be seen from the effort of either the national government or regional government which was the incentive to offer investment to the investors. Not only to the hunters seeking to invest, the governments tempted with the benefits of each investment value also encourage the hunters to package attractive investment packages, such as those found in the case of real estate deals and tourism towns that are government policies in Costa Rica (Van Noorloos, 2011).

Investment in tourism basically overlaps the investment in the general sense; the difference lies solely in the formation of fixed capital (Fixed Capital Information) which is directly related to the development of infrastructure and facilities that can enhance the growth of tourism (Snyman \& Saayman, 2009). Concerning the issue of tourism financing aimed at tourism infrastructure and facilities such as roads, communications networks, utilities, ports, and the others generally financed by the government through the state budget revenues or Regional Revenue Budget also called Tourism Social Investment (Fauzel et al., 2016). Meanwhile, the infrastructure and facilities such as hotels, recreational parks, tourist transport, and the others are conducted by private sectors called tourism- 
Tourism and Development: Land Acquisition, Achievement of Investment and Cultural Change (Case Study Tourism Industry Development in Batu City, Indonesia)

direct investment (Singagerda et al., 2013). In the context of tourism development in Batu City, the investments made in the framework of tourism development are mostly conducted by private sectors. Currently, almost most of Batu tourism objects are owned by private sector, especially tourism destinations categorized as artificial tourism location such are Jawa Timur Park I \& II, BNS (Batu Night Spectacular), Eco Green Park, Batu Wonderland, Museum Angkut \& D'Topeng Kingdom, Predator Fun Park, Museum Tubuh etc. And even the location of the tourism destination is owned by Jatim Park Group. In general, The achievements regarding investments in Batu city always exceed the targets of what has been determined by the Medium-Term Development Plan (RPJMD) proclaimed by the Regional Development Planning Agency (BAPPEDA) of Batu city. The investment in Batu City reached 400 billion in a year. However, the investment data recap was done by Investment Agency (BPM) Batu city until May 2017 in the value of incoming investment reached 900 Billion. In addition, the form of investment is not always in the form of cash money but assets that can move or build the assets.

However, the value of incoming investment in each year is not fully realized. This case is because the funds are not fully absorbed in every development in one year. Hence, the realization of the investment takes place multi years. Nevertheless, obstacle often found in the field is the accountability of investment development reports. In its provisions, the investors should give online report on the progress of how the absorption of funds and allocations is wherever the funds are used. However, in fact, the Investment Agency (BPM) found that such information is difficult to obtain from the investors. Aside from the government, the actors who play a role in the widespread seizure of land in Batu City are caused by the emergence of the land brokers.

These brokers deeply understand the areas to be developed into tourism development projects. They also know the strategic locations that have the best views, so it has great potential for the investors. These brokers work certainly and have a fairly systematic way of working. The first way that they do is through the online land sale by taking pictures of the land location and usually through social media. Furthermore, they also have a broker network in Batu city. They give information each other if there are buyers who want to find the land location. Moreover, they also agreed to the rules of the profits to be shared from the land sale. This way of working is described by Cook (2015) as a 'link-work'. In addition, the way they work is to build relationships with village apparatus to track ownership status and land area in the village. In some cases, village officials are supposedly responsible for the realization of land ownership disposal in their villages because they also provide information of the strategic location of the existing land in the village. Even it has become a common conversation that the village head gets a fee of $1 \%$ of the profits of land selling in his village. Such conditions can be concluded that the real actor who liberalizes the land is not the community but the government itself because the government has never seriously protected the land either owned by the community or village.

Moreover, the mechanism of land acquisition occurs in a variety of ways. White (2012) explained that during the colonial period land acquisition occurred by manipulating the 'empty' land (though it obviously had been mastered and used traditionally) into 'no-man' land (no owner) and making it 'official' state property. At the end of the colonial or post-independence period many countries and civil society were attempting to correct the historical distortions with land reform and so on, to end a broad pattern of private ownership and to distribute the land to poor people. In the mid-2oth century, the World Bank also did the same thing as a strategy of agricultural development. Today, many governments and international organizations support the 
land acquisition executed by giant corporations (both domestic and foreign corporation), usually in the form of long-term concessions as well as compensation, in the name of 'development'. The dynamics of land acquisition grows more than the desire for agribusiness accumulation rather than development needs. However, theoretically, Taylor and Bending (2009) categorized the mechanism of land acquisition in two forms, namely illegal and legal. The illegal mechanism is the process of land grabbing through a land transaction agreement that intercepts formal procedures or also the use of military violence, while the legal mechanism is the process of land acquisition through formal procedures. The forms of investment that can be found are the sale and purchase (lease) of both long term lease and short term lease. The two most common forms of investment made in Asia are leases which are conducted in two ways; 1) the government leases large state lands to foreign corporations and 2) foreign investors use a joint venture scheme or partnership with corporations or domestic landowners. Referring to the categorization of Taylor and Bending (2009), land Acquisition in Batu City is more likely to be legal. Even Batu city government tends to provide convenience to the investors who want land investment in Batu City. Various efforts or facilitating are done to keep the investor willing to invest the land. Firstly, the effort is to collect Local Government Work Unit (SKPD) with investors to form a team to accelerate the investment. Secondly, the Mayor also provides a mandate to the village apparatus (village head) to find information of the land ownership status.

However, some of the conveniences provided by Batu city government triggered a gap and in some cases violated formal jurisdiction. German (2011) explained that there are at least five gaps in the implementation of legislation, (1) many projects are implemented without approval (either investment permit, land certificate, or environmental permit). In the absence of an application that is considered legally valid and supervisory in implementation, government action has ignored the consultation procedures with customary rights holders); (2) it is found an attempt to establish an agroecological zone; (3) the restrictions of duration in leasing alot of land are violated; (4) failure of agreement in the consultation process to place the community on the free, prior and informed principles. The consultation process is weak despite legally mandated procedures; (5) the absence of investment supervision and sanctions for offenders. At least, the categorized gaps described by German (2011) have occurred in Batu City.

Some cases that occur among others are: First, the development of Predator Park in Junredjo district does not have Building Permit (IMB). In addition, the location as used the tourism area is a productive land. Secondly, the existence of the Jambuluwuk resort that violates the rules of the environment that is the location of the resort is built on the location of the land with a slope of 45 degrees. Furthermore, the area is a water catchment area building on it could reduce the absorption potential so that is possibly cause landslides. Thirdly, the thing which is still a polemic is the development plan of Rayja Hotel located in Gemulo springs area. In this case, the government deliberately hits a predetermined rule. From the recommendation made by Development Planning Agency (BAPPEDA) the area is not allowed for the building of hotel but it is recommended for development of cottages or bungalows. However, the licensing that comes out in the integrated licensing office is the building of hotel. Furthermore, the main way that the Batu City government did to make communities relinquish their land to investors under the pretext of their underground is 'unproductive land' or marginal soils that need to be utilized for development. White (2012) explained that the government always strives to initiate policies and administration around the concept of 'marginal soils' and facilitate land investment that involves invention / justification, definition, reclassification, 
Tourism and Development: Land Acquisition, Achievement of Investment and Cultural Change (Case Study Tourism Industry Development in Batu City, Indonesia)

quantification, identification, acquisition/takeover and reallocation or disposition. All these thing areused to transform resources (largely in state control) into productive factors of production to renew large-scale land-based investments. In addition to this identification, land acquisition is also referred to as an answer or solution to the crisis.

However, in fact, there is a lot of land acquisition of land lots of land that have a negative impact. The general effect is the eviction of small peasants (Quizon, 2012; Kodir \& Mushoffa, 2017). Moreover, the land acquisitions contributes to rise the food prices, make the poor and food shortages more vulnerable, exacerbate the instability and inequalities, create conflicts among stakeholders (especially ethnic groups) as a result of less control over natural resources, as well as related to the usual dark practices (Arduino, 2012). In the context of this research, the land acquisition in Batu City caused the increase in land prices. This case is because in accordance with the economic principle when there is a scarcity of commodities, the direct selling price of these commodities will rise as demand in the market is also quite high. The amount of land in Batu City is limited. It is because administratively Batu city only consists of 3 districts and 19 villages. On the other hand, the need for the tourism industry and trade will continue to increase. Furthermore, the land acquisition happened in Batu City caused the decline in the number of crop production and reduced the agricultural land area (Table 1).

Table 1. Statistics of Food Crops (Source: Statistical Central Agency of Batu City, 2015)

\begin{tabular}{|cccc|}
\hline & $\mathbf{2 0 1 2}$ & $\mathbf{2 0 1 3}$ & $\mathbf{2 0 1 4}$ \\
\hline Rice & & & \\
\hline wide of harvest (ha) & 1157 & 863 & 741 \\
Production (ton) & 7405 & 5523 & 4607 \\
\hline Corn & & & \\
\hline wide of harvest (ha) & 1030 & 497 & 488 \\
Production (ton) & 4120 & 1938 & 1838 \\
\hline Cassava & & & \\
\hline wide of harvest (ha) & 100 & 52 & 27 \\
Production (ton) & 1700 & 1667 & 864 \\
\hline
\end{tabular}

One of the main factors causing the decline in the number of food crop production and the reduction of agricultural land area is the impact of tourism industry development that rises significantly every year. Almost all of the major tourism sites and their supporting facilities (hotels, villas and restaurants) are built on agricultural land. Although the land acquisition in Batu City is significant, there is no movement from the community to reject or resist. This is different in the other parts of Indonesia where the procurement of land for development always creates protests by peasants, local communities or indigenous peoples. Despite it all, the movement is not a common issue at the national level. It is different from some areas in India and China. The results of research of Ren (2017) showed that the land acquisition in the region of India and China triggered protests from peasants and met at the national level.

Tourism Design, Spatial Reorganization and Cultural Change

The establishment of Batu city as a tourism city was originally established by the first mayor of Batu city, Imam Kabul, where the concept of tourism is based on agriculture (Yunanto, 2015) by emphasizing the production of agricultural products. However, the concept of tourism city development became massive in the era of the Mayor after him, namely Edy Rumpoko, precisely in 2007 then in the branding into Batu Tourism City $(K W B)$. In the early period, the vision of Batu Tourism City was to be the main destination of tourism destinations in East Java, Indonesia. In that era, the Batu city 
has succeeded in increasing the local revenue ( $P A D)$ derived from tourism destination tickets, hotel and restaurant taxes. In period 2, the vision of Batu Tourism City was developed into 'a center of organic agriculture based on the international tourism'. This concept is then implemented through the regulation of Regions Development of Organic Farming. The existence of this regulation first encourages certification of organic agricultural areas and agricultural products. In addition, the existence of the Regulation of Regions Development of Organic Agriculture can be a tool of coercion to all stakeholders to participate in the success of this organic farming program.

However, the existence of organic farming has not had a big contribution for regional income like artificial tourism. Moreover, to achieve the sustainability with regional development, Batu city government provides clear legal payments. The act certainty is designed through the Regional Regulation of Regional Tourism Development Master Plan (RIPPARDA). This regulation is intended as an integrated regulation and regulatory system in the development of tourism in Batu city, which includes: tourism destinations, tourism industry, tourism marketing and tourism institutions. Furthermore, the existence of the regulation aims to provide legal certainty to the stakeholders of tourism in doing tourism development in the city of Batu. The existence of the Regional Regulation of Regional Tourism Development Master Plan (RIPPARDA) supports Lefebvre's (1992) statement that capitalism is maintained by conquest and integration of space. Space has ceased to be a passive geographical environment or an empty geometric space for along time. Spaces becomes the instrumental and the media of the development of capitalism. That is, space is a system seen as a scarce, homogeneous resource, has quantitative commodities and exchange rates traded like any other commodity in the market.

Through the Regional Regulation of Regional Tourism Development Master Plan (RIPPARDA), the spatial planning of Batu city depends on the needs of the investors to invest their capital for the development of the tourism industry. It is because after all, spatial planning is never free from the alignment of actors who make spatial arrangements. The alignment or non-neutrality of actors in exercising their power is reflected in the policies made by the regulator (the government) (Aminah, 2015). Such conditions reinforce what Zoomers (2010) calls 'Foreiginisation of Space' where the ownership of space over local communities is then controlled by foreigners. Although the acquisition or possession by foreigners is not new, the current trend is increasing massively with a scale of intensity that increases significantly. Governments in developing countries tend to indulge foreign investors with the appeal of capital provided. This case is because the development or underdevelopment of an area or urban area is measured by the presence or absence of capitalist investment flows (Harvey, 1985, 2001). Tourism as a product of capitalism (Mosedale, 2011) requires a special spatial reorganization so that the capitalistic patterned production system can expand geographically (Harvey, 1985, 2001). The term here is more broadly meaningful than the term the government calls "spatial planning" (Rachman, 2015). Generally, what is meant by the term space in "spatial reorganization" here includes: (a) imagination and depiction spaces, including technocratic designs termed master plan, grand design, and so on; (b) material space, the place where we live; and (c) spatial practices of various parties in the making of space, utilization of space, modification of space, and the elimination of space, in the context of various efforts to meet the needs, including those in positions of state, corporation, or the people (Lafebrve, 1992).

The reorganization of space is perpetuated by companies that intend to continue to double profits and avoid losses. In the context of Batu reorganization of space conducted by investors through the construction of artificial tourism location which is also then followed by facilities of hotel development, restaurant becomes a supporter of tourism. 
Tourism and Development: Land Acquisition, Achievement of Investment and Cultural Change (Case Study Tourism Industry Development in Batu City, Indonesia)

The benefits gained through the tourism industry and its supporting sectors (hotels, restaurants, etc.) are essentially derived from the privatization of land and natural resources, the separation between the producer and the owner of the goods produced, and the exploitation of labor to produce value-added merchandise. The commodities or merchandise produced by the capitalist system of production are transported in such a way from where they are produced to commerce and consumption of the people, both to meet the necessities of life and to serve the shopping habits (Rachman, 2015).

The reorganization of space as a result of the opening of new spaces for capitalism often influences on the changes and values of cultural elements that have previously been socially bound in those places (Rachman, 2012). The development of Batu tourism that tends to the modern direction has a substantial contribution to the cultural change of society in Batu city. This case also happens in some areas in Africa, especially in small-scale society (Mansperger, 1995). Woods (1980) called it a cultural institution. Tourism is a truly powerful and unique force for change in community (Macleod, 2004). Moreover, this is since the development of promoted tourism is a mass product that anyone can make. So, it does not become a differentiator with the other tourism in Indonesia. Although in every year Batu city organizes cultural festivals by displaying various cultural activities, it is just a routine. It is not the real meaning of culture unearthed from the values of the social traditions. In general, the design of tourism development adopts many of the existing tourism models in Singapore, which emphasizes artificial tourism products with a variety of rides and games. The development of Batu city tends to move away from the cultural artefacts owned by Batu city community. Such conditions explicitly have an impact on the changing mentality of Batu city society. For example, Batu city community currently tend to be more interested in working in non-agrarian sectors that expect results so quickly. Consequently many of them left the agricultural sector that had been cultivated previously.

\section{CONCLUSION}

Land acquisition for development plans by both state and private institutions is inevitable. Of course, the expected development goal is to have an impact on national economic growth to the region. In addition to the effect on the development of economic growth, the achievement of development should make a significant influence on the welfare of the community. As a new city, Batu city also contributes to the development efforts. The realization of the development effort is certainly with any potential capital owned. Currently, the great potential of the Batu city is tourism. Even, through the development of Batu city tourism, the regional income reached around 100 billion and regional economic growth achieved 8.03\% (Statistical Central Agency, 2016). In addition, the achievement of investment value always exceeds the targets set in the Medium Term Plan (RPJMD). However, the great successes have the consequences of triggering land acquisition process. The land acquisition process is triggered by the high demand for land in Batu city to serve as a tourism location. Aside from tourism, the acquisition process is also influenced by the expansion of business and trade, especially the development of hotels, villas, restaurants or any facilities that support tourism potential. The process of land acquisition in Batu city involves several factors such as investors, governtment, village government apparatus and brokers. Those actors have relations, especially the land brokers with the village apparatus who have a lot of information of the status of land ownership in Batu city area. Moreover, this study also shows that Batu City spatial planning change depends on capital investment in the tourism sector. It can be proved through what has been stipulated the Regional Regulation of Regional Tourism Development Master Plan (RIPPARDA) by the government because as a product of capitalism, tourism requires a 
reorganization of space for a capitalist-patterned production system to extend geographically. The spatial reorganization is perpetuated by private sectors that intend to continue to double profits and avoid losses. Consequently, the spatial reorganization affects the changes of cultural elements value that have previously been socially bound.

\section{Aknowlegments}

I would like to thank Faculty of Social Science, Universitas Negeri Malang that has given researcher funding through BLU Program.

\section{REFERENCES}

Aminah, S., (2015), Konflik dan Kontestasi Penataan Ruang Kota Surabaya, Masyarakat: Jurnal Sosiologi, vol. 20, no. 1, pp. 57-59.

Agustina, T., (2008), Analisis Daya Saing Apel Tropis Di Kota Batu, Jurnal Sosial Ekonomi Pertanian, vol. 2, no. 2, pp. 23-31.

Arduino, S., (2011), Contamining of Community Potable Water from Land Grabbing: A Case Study from Rural Tanzania, Water Alternative Journal, Vol. 5, No. 2.

Assembe-Mvondo, S., Colfer, J., P.,C., Brockhaus, M., Tsanga, R., (2014), Review of the Legal Ownership Status of National Lands in Cameroon: A More Nuanced View, Development Studies Research, vol. 1, no. 1.

Bollin, A., (2011), Fenomena Global Perampasan Tanah, DTE 89.90.

Capucci, M., (2016), Indigenous Tourism In The Amazon Region Of Suriname: Actions To Preserve Authenticity And Natural Resources, GeoJournal of Tourism and Geosites, vol. 17, no. 1, pp. 47-56.

Cárdenas-García, P., J., Sánchez-Rivero, M., Pulido-Fernández, I., J., (2015), Does Tourism Growth Influence Economic Development?, Journal of Travel Research, vol. 54, no. 2, pp. 206-21.

Chettiparamb, A., (2016), Articulating 'Public Interest' through Complexity Theory, Environment and Planning C: Government and Policy, vol. 34, no. 7, pp. 1284-1305.

Cook, I, M., (2015), Link Work: Land and Housing Brokers in Mangaluru, India, Journal of South Asian Development, vol. 10, no. 3, pp. 292-317.

Dinda, S., (2016), Land Acquisition and Compensation Policy for Development Activity, Journal of Land and Rural Studies, vol. 4, no. 1, pp. 111-18.

Du, D., Lew, A., A., Ng, P., T., (2016), Tourism and Economic Growth, Journal of Travel Research, vol. 55, no. 4, pp. 454-64.

Eugenio-Martin, J., L., Martín-Morales, N., Sinclair, M., T., (2008), The Role of Economic Development in Tourism Demand, Tourism Economics, vol. 14, no. 4, pp. 673-90.

Fauzel, S., Seetanah, B., Sannassee, R., V., (2016), Analysing the Impact of Tourism Foreign Direct Investment on Economic Growth: Evidence from a Small Island Developing State, Tourism Economics, vol. 23, no. 4.

German, L., Schoneveld, G., Mwangi, E., (2011), Contemporary Process of Large Scale Acquisition, World Development, vol 48, pp. 1-18.

Ginosar, A., (2014), Public-Interest Institutionalism: A Positive Perspective on Regulation, Administration \& Society, vol. 46, no. 3, pp. 301-17.

Hamidah, U., (2014), Politik Hukum Pengaturan Pengadaan Tanah Untuk Pembangunan Bagi Kepentingan Umum, Praevia, vol. 6, no. 1, pp. 1-12

Harvey, D., (1985) The Urbanization of Capital: Studies in the History and Theory of Capitalist Urbanization. Oxford UK: Blackwell.

Harvey, D., (2001), Spaces of Capital: Towards a Critical Geography. Edinburgh: Edinburgh University Press.

Hasanah, U., (2012), Implementasi Politik Hukum Dalam Pengadaan Tanah Bagi Pelaksanaan Pembangunan Untuk Kepentingan Umum, Jurnal Ilmu Hukum, vol. 2, no. 4, pp. 23-31.

Karmakar, P., (2017), Politics of Development: Land Acquisition and Economic Development in India, Journal of Land and Rural Studies, vol. 5, no. 2, pp. 164-82.

Kim, N., Song, H., Pyun, J., H., (2016), The Relationship among Tourism, Poverty, and Economic Development in Developing Countries: A Panel Data Regression Analysis, Tourism Economics, vol. 22, no. 6, pp. 1174-90.

Kodir, A., Mushoffa, I., (2017), Islam, Agrarian Struggle, and Natural Resources: The Exertion of Front Nahdliyin for Sovereignty of Natural Resources Struggle Towards Socio-Ecological Crisis in Indonesia, Karsa: Journal of Social and Islamic Culture, vol. 25, no. 1, pp. 57-89.

Kristian, Di., Suyatna, I., N., Dahana, C., D., (2014), Kewenangan Pemerintah Daerah Dalam Pengadaan Tanah Bagi Pelaksanaan Pembangunan Untuk Kepentingan Umum.” Kertha Negara, vol. 2, no. 01, pp. 1-9.

Langgeroni, R., (2015), Pelaksanaan Pengadaan Tanah Hak Milik Perorangan Oleh Pemerintah Daerah Untuk Kepentingan Umum, Lex Et Societatis, vol. 3, no. 6, pp. 21-32.

Lefebvre, H., (1992), The Production of Space, Donald Nicholson-Smith (Translator), London: WileyBlackwell

Lennon, M., (2017), On 'the Subject' of Planning's Public Interest, Planning Theory, vol. 16, no. 2, pp. $150-68$. 
Tourism and Development: Land Acquisition, Achievement of Investment and Cultural Change (Case Study Tourism Industry Development in Batu City, Indonesia)

Macleod, D., VL., (2004), Tourism, globalisation, and cultural change: An island community perspective. Vol. 2. Channel View Publications.

Mansperger, M., (1995), Tourism and cultural change in small-scale societies, Human Organization, vol. 54, no. 1, pp. 87-94.

Maulida, H., F., Anggoro, S., Susilowati, I., (2012), Pengelolaan wisata alam air panas cangar di Kota Batu, Ekosains, vol. 4, no. 3, pp. 20-31.

Mosedale, J., (2011), Political Economy of Tourism: A Critical Perspective, London and New York: Routledge.

Muzha, V., K., (2013), Pengembangan agrowisata dengan pendekatan Community Based Tourism (Studi pada Dinas Pariwisata Kota Batu dan Kusuma Agrowisata Batu), Jurnal Administrasi Publik, vol. 1, no. 3, pp. 135-141.

Parwez, S., Sen, V., (2016), Special Economic Zone, Land Acquisition, and Impact on Rural India, Emerging Economy Studies, vol. 2, no. 2, pp. 223-39.

Pujiriyani, W., D., Putri., V., R., Yusuf, M., Arifin, M., B., (2014), Land Grabbing: Bibliografi Beranotasi, Yogyakarta: STPN Press.

Rachman, N., F., (1997), Tanah dan Pembangunan, Jakarta: Pustaka Sinar Harapan.

Rachman, N., F., (2012) Land Reform: Dari Masa Ke Masa, Yogyakarta: Tanah Air Beta.

Rachman, N., F., (2015) Memahami Reorganisasi Ruang Melalui Perspektif Politik Agraria, Bhumi Vol. 1, No. 1, Mei 2015, pp 33-4.

Rahayu, A., Bambang, A., N., Hardiman, G., (2013), Strategi Peningkataan Status Keberlanjutan Kota Batu Sebagai Kawasan Agropolitan, Ekosains, vol. 5, no. 1, pp. 42-54.

Ren, X., (2017), Land Acquisition, Rural Protests, and the Local State in China and India, Environment and Planning C: Politics and Space, vol. 35, no. 1, pp. 25-41.

Salim, A., (2006), Teori dan Paradigma Ilmu Sosial, Yogyakarta: Tiarawacana.

Senduk, S., E., (2015), Pengadaan Tanah Bagi Pembangunan Untuk Kepentingan Umum Berdasarkan Undang-Undang No. 2 Tahun 2012, Lex Et Societatis, vol. 3, no. 5, pp. 1-15.

Singagerda, F., Santi, I., Oktaviani, R., Hakim, D.B., Kustiari, R, (2013), Analisis aliran investasi dan perdagangan pariwisata Indonesia, Bina Ekonomi, vol. 17, no. 2, pp. 56-67.

Snyman, J., A., Saayman, M., (2009), Key Factors Influencing Foreign Direct Investment in the Tourism Industry in South Africa, Tourism Review, vol. 64, no.3, pp. 49-58.

Sopandi, A., Nazmulmunir, N., (2013), Pengembangan iklim investasi daerah, Jurnal Kybernan, vol. 3, no. 1, pp. 67-73.

Sukmana, O., (2012a), Konsep Pemberdayaan Masyarakat Melalui Pengembangan Komunitas Berbasis Potensi Lokal (Studi Di Desa Wisata Bunga Sidomulyo, Kota Batu-Jawa Timur, Jurnal Humanity 6 (1).

Sukmana, O., (2012b), Model Pengembangan Lingkungan Kota Ekowisata (Studi di Wilayah Kota Batu), Jurnal Humanity, vol. 5, no. 1, pp. 23-34.

Taylor, M., Bending, T., (2009), Increasing Commercial Presure on Land: Building a Coordinated Response, Rome: International Land Coalition.

Thompson, A., (2011), Terrorism and Tourism in Developed versus Developing Countries, Tourism Economics, vol. 17 , no. 3, pp. 693-700.

Quizon, A., (2012), The Rush for Asia's Farmland: Its Impact on Land Rights and Security of the Rural Poor, LOK NITI, vol. 18, no. 1, pp 7-18.

Vanegas, M., Gartner, W., Senauer, B., (2015), Tourism and Poverty Reduction: An Economic Sector Analysis for Costa Rica and Nicaragua, Tourism Economics, vol. 21, no. 1, pp. 159-82.

Van, Noorloos, F., (2011), Residential Tourism Causing Land Privatization and Alienation New Pressure on Costa Rica Coasts, Development, vol. 54, no.1 pp. 85-90.

Wangke, T., N., (2016), Pengadaan Tanah Bagi Pembangunan Untuk Kepentingan Umum Di Indonesia, Lex Administratum, vol. 4, no. 4, pp. 77-86.

White, Ben., Saturnino, M., B., Jr., Hall, R., Scoones, I., Wolford, W., (2012) The new enclosures: critical perspective on corporate land deals, The Journal of Peasant Studies, vol. 39, no. 3-4, pp. 619-647.

Wirabrata, A., Surya, A., (2011), Masalah Kebijakan Dalam Pengadaan Tanah Untuk Pembangunan Infrastruktur, Jurnal Ekonomi dan Kebijakan Publik, vol. 2, no. 2, pp. 729-752.

Wood, R., E., (1980), International tourism and cultural change in Southeast Asia, Economic Development and Cultural Change, vol. 28. no. 3, pp. 561-581.

Yunanto., (2015), Pokja Pendiri Kota Batu, Malang: Bentara.

Yonanda, I., (2013), Efektivitas Pelayanan Izin Mendirikan Bangunan (IMB) Dalam Sektor Industri Pariwisata Di Kota Batu (Studi pada Kantor Pelayanan Perizinan Terpadu Kota Batu), Jurnal Administrasi Publik, vol. 1, no. 1, pp. 70-78.

Zoomers, A., (2010), Globalisation and the Foreignisation of Space: Seven Processes Driving the Current Global Land Grab, The Journal of Peasant Studies, vol. 37, no. 2, pp. 429-47.

*** Statistical Central Agency, (2015), Statistik Daerah Kota Batu 2015.

*** Statistical Central Agency, (2016), Statistik Daerah Kota Batu 2016.

Submitted:

03.12.2017
Revised:

16.03.2018
Accepted and published online 20.03.2018 